\title{
Changes in the Communication Strategy of Barcelona's Digital Economy in Response to the COVID-19 Crisis
}

\author{
Patricia Coll-Rubio \\ Ramon Llull University (Spain)
}

This article presents the results of a study carried out using data provided by professionals responsible for planning and executing communication strategies for 30 leading companies involved in the digital economy of Barcelona, site of the Mobile World Congress technological trade show, which was cancelled in 2020 due to the COVID-19 health crisis.

The results of the study, carried out electronically from 1-15 April 2020, show that $77 \%$ of the technology companies that participated in the study changed their strategic communication planning during the first month of the state of alarm declared by the Spanish government on 14 March 2020. In $73 \%$ of cases, the strategy was proactive, although with a new orientation. The resulting mix of actions included preparing and dissem- inating digital content, sending press releases, organising digital events, generating internal communication and, to a lesser extent, advertising, following a strategy that combined $60 \%$ of owned media, $27 \%$ of earned media, and $13 \%$ of paid media. During the first month of the state of alarm in response to COVID-19, social media was the main communication channel for the digital companies that participated in the study, compared to print media, television, and radio. $30 \%$ of these communication actions used newsjacking techniques, tying their messages to the current situation of the pandemic.

Keywords: digital communication, social media, crisis communication, public relations, content marketing, event organisation, newsjacking.

The study that produced the results presented in this article aimed to find out whether there was a redefinition in the communication strategies of companies in Barcelona's digital economy during the first weeks following the Spanish government's declaration of a state of alarm as a result of the COVID-19 pandemic (RDL 463/2020, dated 14 March). 
Barcelona is the fifth European hub in terms of volume of start-ups (Atomico, 2019) and has served as the headquarters for the Mobile World Congress technological congress since 2006. It is slated to continue in that role until at least 2024 (GSMA, 2020b), although the 2020 edition, which was due to begin on 27 February, was cancelled by the organising entity (GSMA, 2020a) as a measure to prevent the spread of the novel coronavirus from the Wuhan area (China) to other areas of the world. This decision, which was preceded by a series of companies cancelling trips to large events, was supported at the time by $57 \%$ of the professionals at the Barcelona-based technology companies that participated in the study. 53\% of respondents participated in various parallel events that were organised in the city following the cancellation of the international congress. Two months later, the decision was supported by $100 \%$ of the respondents in this study.

Beyond providing perspective on the cancellation of the Mobile World Congress, the analysis of decisions made by the Barcelona technology sector regarding communication strategies in response to the COVID-19 crisis in Spain has value for research in various communication disciplines, including digital marketing, advertising, journalism, corporate communication and public relations. It also helps explore approaches to crisis communication (Jin, 2010; Jin, Liu, and Austin, 2012; Coombs, 2014; Fearn-Banks, 2016) among digital native companies (Prensky, 2001) at a time -during the state of alarm (RDL 463/2020, dated 14 March) - when communication was focused almost exclusively on messages related to the pandemic, and the internet became the main channel (Castells, 2004) due to the confinement declared by the Spanish government to combat the health emergency in the country caused by the novel coronavirus (Legido-Quigley et al., 2020; Micó and Coll, 2020).

\section{THEORETICAL FRAMEWORK}

Increasingly, the digitisation of the communication process has been accelerating. Since the popularisation of the Internet beginning three decades ago with the arrival of the World Wide Web - and especially since the advent of social media just over 10 years ago - society has gone from relating, informing, and entertaining itself through analogue channels to doing so, increasingly, through digital channels (Wellman and Haythornthwaite, 2002; Castells, 2004; Thompson; 2005; Howard, 2006; Qvortrup, 2006; Dubber, 2014; Chaffey and Ellis-Chadwick, 2019; Miller, 2020), especially among the generations born since this digitisation process began (Prensky, 2001).

The health crisis derived from the COVID-19 pandemic led to a catharsis in this transition, as well as a watershed moment in adapting communication strategies to the digital landscape (Grunig and Hunt, 1984; Austin and Pinkleton, 2000; Wilcox, Cameron, and Xifra, 2012; Smith, 2013) across all disciplines, including marketing, advertising, journalism, corporate communication and public relations, which have been faced with an increasingly complex communication paradigm in recent years (Howe and Teufel, 2014; Campbell and Marks, 2015; Pulizzi, 2015). 
Communication professionals plan and execute strategies that aim to con-

nect with audiences, interacting with them and creating ties to turn them into allies to spread their messages, sometimes even making them go viral (Rushkoff, 1994; Jurvetson and Draper, 1997; Rosen, 2002; Berger and Milkman, 2012; Maskeroni, 2016). These strategies are developed in an integrated manner (Schultz and Kitchen, 2000; Kotler, 2003; Kliatchko, 2005), combining actions from different disciplines, such as marketing, advertising and public relations, to take advantage of synergies and maintain coherence in the eyes of their audiences.

In terms of the classification of actions, communication professionals from the digital economy sector distinguish between owned media, earned media and paid media (Tuten and Solomon, 2018: 22; Aced, 2018: 67-68), where owned media is defined as the organisation's own corporate channels, including the management of digital content on websites, blogs, newsletters or social networks; paid media refers to advertising or branded content, in any of its possible formats, and earned media refers to actions of corporate communication, public relations and publicity which generate recognition in third-party sources, such as appearances in the media or mentions on social networks.

In the specific case of digital native brands (Prensky, 2001), which have emerged in the context of the new economy (Kelly, 1997), the list of actions also includes publicity (Bernays, 1923; Marston, 1963; Steinberg, 1975; Grunig and Hunt, 1984; L'Étang, 2009; Wilcox, Cameron, and Xifra, 2012) and digital marketing (Brown and Hayes, 2008; Pulizzi and Barrett, 2009; Kaushik, 2010; Tuten and Solomon, 2018), which adopt a growth hacking approach (Ellis, 2010; Chen, 2012; Holiday, 2014; Patel and Taylor, 2014; Ellis and Brown, 2018) that combines creativity and analysis to achieve an increase in visibility and the spread of the brand's messages.

With regard to their positioning strategy in the context of communicating a crisis (Jin, 2010; Jin, Liu, and Austin, 2012; Coombs, 2014; Fearn-Banks, 2016) that has taken over the media focus (McCombs and Shaw, 1972 ), as in the case of the COVID-19 pandemic, we see the technique of newsjacking, which consists of spreading brand messages in relation to a current event (Scott, 2010; Scott, 2011; Coll and Micó, 2019).

\section{METHODOLOGY}

The study, which aimed to find out whether there was a redefinition of the communication strategies of companies in Barcelona's digital economy during the first weeks following the Spanish government's declaration of the state of alarm as a result of the COVID-19 pandemic (RDL 463/2020, of March 14), was carried out electronically from 1-15 April 2020. The responses, therefore, reflect the strategic communication decisions made by the technology companies under study during the first month following the Spanish government's declaration of the state of alarm on 14 March 2020 in response to the health crisis resulting from the spread of the novel coronavirus among the population. 
The completion of the survey had to be carried out exclusively online due to the tightening of the confinement measures announced by the Spanish government after the extension of the state of alarm, which included stay-at-home orders, with the exception of essential workers in industries like healthcare or in the supply chain, to limit the mobility of the population in the context of the fight against COVID-19 (RDL 10/2020, dated 29 March).

The survey consisted of two sets of questions. The first set focused on study participants' opinions regarding the cancellation of the Mobile World Congress, using closed-ended questions about their degree of conformity with the decision to suspend the congress, both at the time the suspension occurred and later on, after the virus had spread to Spain. The second set of questions focused on the communication strategies implemented following the declaration of the state of alarm in response to the COVID-19 health crisis in Spain (RDL 463/2020, dated 14 March), combining closed-ended questions with open-ended questions related to the initial responses in order to compile more specific information for use in interpreting the results.

The survey was filled out by the professionals responsible for planning and executing the communication strategies for 30 leading technology organisations in Barcelona's digital economy, including Adevinta, Airbnb, Barcelona Tech City, Barcelona Health Hub, Community of Insurance, ByHours, Capital Cell, Creative Zoo, Comboca, Cyberclick, Engidi, Epitech, Famileo, Innomads, IRB Barcelona, Housfy, Logisch, Marfeel, Mediktor, MiCuento, Newsworthy Comunicación, Payment Innovation Hub, Ruth Amat Comunicación, Tiendeo, Smartfinance, Social Car, Storydata, Virtuo, Wallapop and WERock Capital.

The survey method, especially suited to obtaining information quickly and in a short period of time (Cea d'Ancona, 1996: 239, 284), has been used before in the field of communication research (Sallot, Cameron, and Lariscy, 1997; Cuenca-Fontbona, Matilla, and Compte-Pujol, 2020). The development of the questions took into account the results obtained to date in research carried out over the last seven years, combining the methods of in-depth interviews and documentary analysis in tracking the communication strategies of Barcelona's technology companies, within the framework of this line of research. 


\section{RESULTS}

The results of the investigation reveal the decisions made by those responsible for strategic communication planning for 30 leading technology companies in Barcelona's digital economy during the first month of the state of alarm declared by the Spanish government in response to the COVID-19 health crisis (beginning from the Spanish government's declaration of the state of alarm) as well as their positions regarding the decision to cancel the 2020 edition of the Mobile World Congress (GSMA, 2020a) on 12 February, just 15 days before it was set to open, as a preventive measure against the spread of the virus from the Wuhan area (China).

With regard to the survey questions related to the cancellation of the 2020 Mobile World Congress in Barcelona, a clear shift can be seen in the attitudes among communication professionals from Barcelona's technology companies. At the time the decision was made, it was endorsed by just $57 \%$ of the professionals who participated in this study.

Figure 1. Conformity with the decision to cancel the Mobile World Congress on 12 February 2020

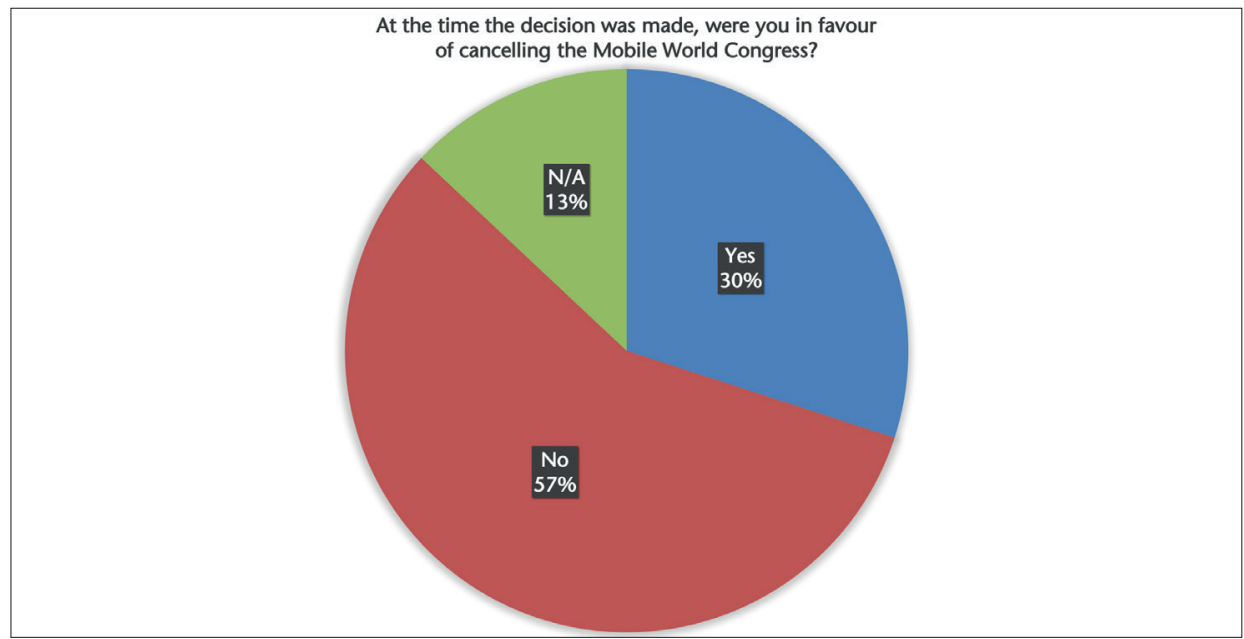

Source: Developed by the author.

However, 53\% of the respondents participated in various parallel events that were organised in the city as an alternative to the suspension of the international congress. 
Figure 2. Participation in alternative events following the cancellation of the Mobile World Congress, held the week of 27 February 2020

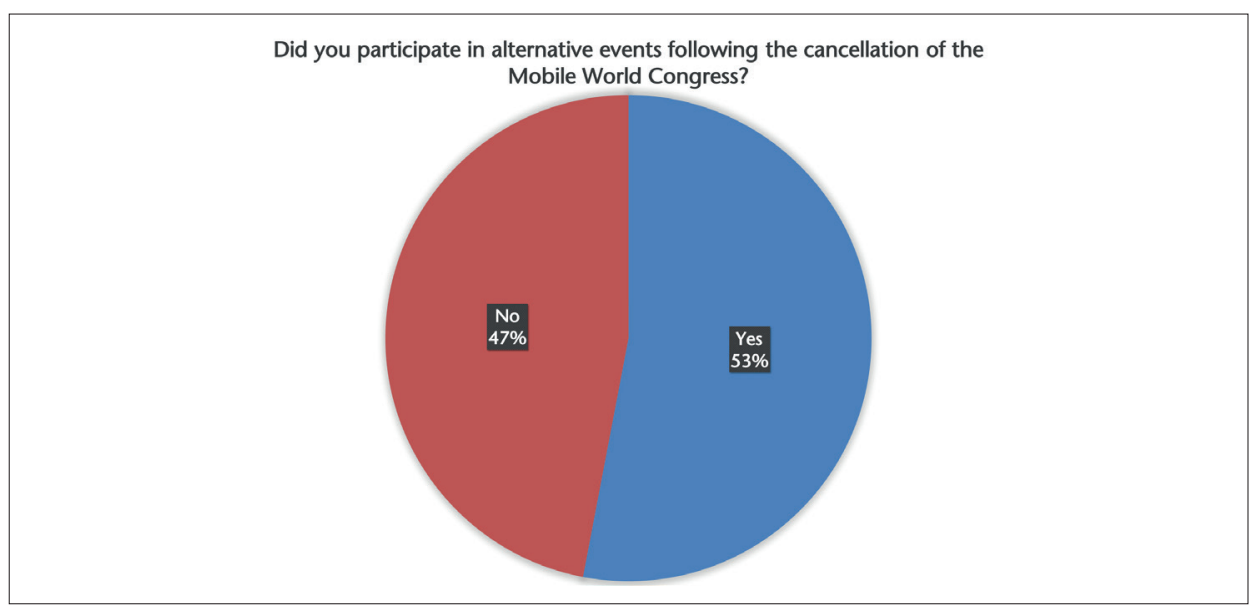

Source: Developed by the author.

At the time of the survey, carried out from 1-15 April 2020, the decision to cancel the Mobile World Congress due to the coronavirus health crisis was fully endorsed by all respondents in the study. 100\% of them responded that, once the COVID-19 pandemic had been declared, they viewed the cancellation of the Mobile World Congress as a wise move.

As for the second set of questions, focused on the communication strategies adopted by the organisations from Barcelona's digital economy that participated in the study, the results reveal that $77 \%$ of those organisations made changes to their strategic planning during the first month of the state of alarm declared by the Spanish government on 14 March 2020 (RDL 463/2020, dated 14 March) and under tightened measures during the following two weeks to prevent the collapse of the country's health system due to the increase in COVID-19 infections and deaths in Spain (RDL 10/2020, dated 29 March).

When describing the new orientation of their communication strategies, the participants in the study highlighted, in their open-ended responses, that the main changes in their strategies included: the suspension of some planned initiatives, mainly offline events and communication actions unrelated to the COVID-19 outbreak; the implementation and communication of solidarity campaigns to contribute to the fight against the pandemic; the offer of solutions to combat COVID-19 or services intended to be useful during the confinement; the reduction of advertising budgets and the increase in organic activity in owned and earned media, mainly centred on digital channels, both through content creation and through press office actions, and the organisation of digital events. 
Figure 3. Changes in communication strategies as a result of the declaration of the state of alarm in Spain in response to the COVID-19 pandemic

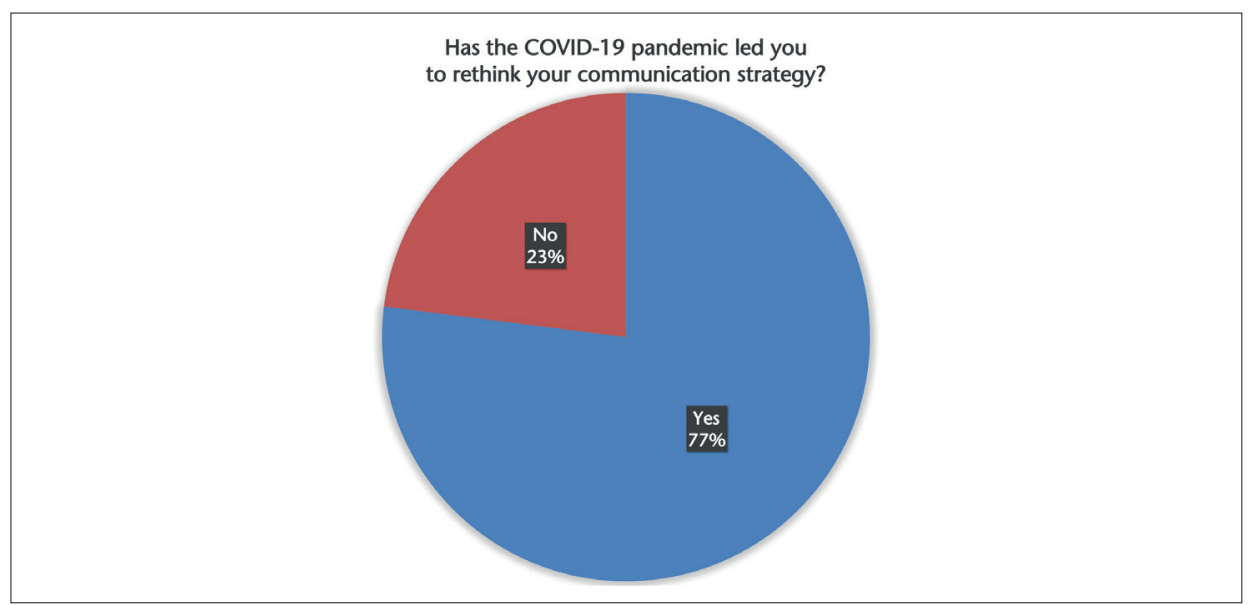

Source: Developed by the author.

The approach of the communication strategies adopted by the organisations from Barcelona's digital economy during the first month following the declaration of the state of alarm was proactive (Smith, 2013) in 73\% of cases, according to the participants in the study. Thus, the digital economy took an active role in response to the COVID-19 health crisis, planning and executing communication actions as opposed to only reacting to the different influences from the surroundings — as a defence or as an opportunity-. However, 27\% of the communication professionals participating in the study adopted a reactive attitude for their organisations during the first month after the Spanish government's declaration of the state of alarm. 
Figure 4. Communication strategy during the COVID-19 crisis

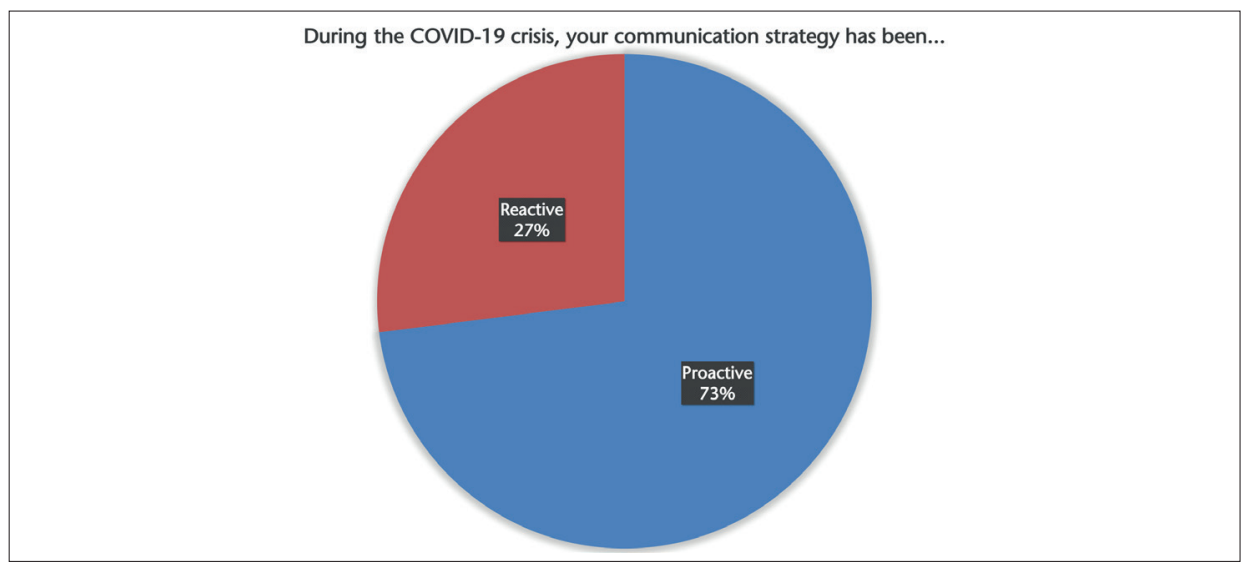

Source: Developed by the author.

As has been pointed out, the digital economy classifies communication strategies across three typologies: owned media, earned media, and paid media (Tuten and Solomon, 2018: 22; Aced, 2018: 67-68). Following this classification, during the first month after the declaration of the state of alarm in Spain in response to the COVID-19 health crisis, the communication strategies of the participating digital economy organisations focused on owned media in $60 \%$ of the cases, although earned media were also considered in the mix in $27 \%$ of cases, as well as paid media, accounting for $13 \%$.

Figure 5. Communication strategy, according to the classification of owned, earned, or paid media

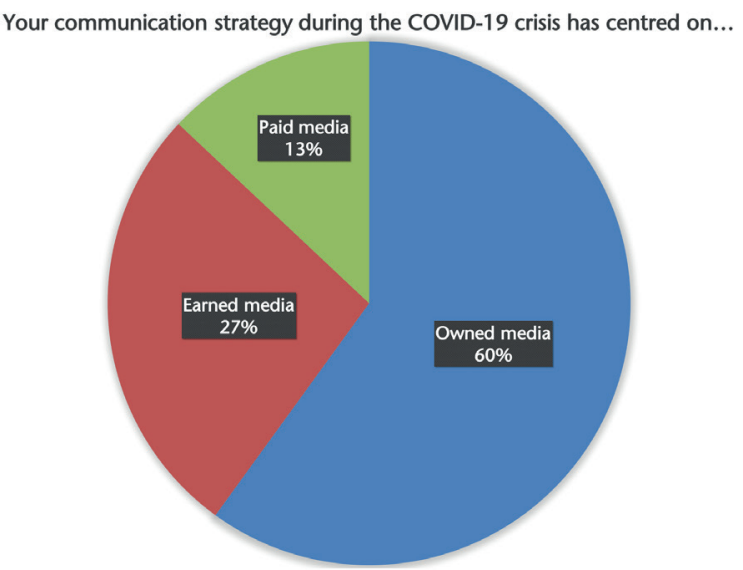


Specifically, the communication actions carried out by the companies from Barcelona's digital economy that participated in this study included: the preparation and dissemination of digital content — carried out by $90 \%$ of the companies-; sending press releases; the organisation of digital events; internal communication actions — used by half of the participants—, and, to a lesser extent, advertising - present in only 15\% of the communication plans of Barcelona's digital organisations during the first month after the state of alarm was declared in Spain-.

Figure 6. Communication actions carried out by communication professionals in Barcelona's digital economy in response to the COVID-19 crisis

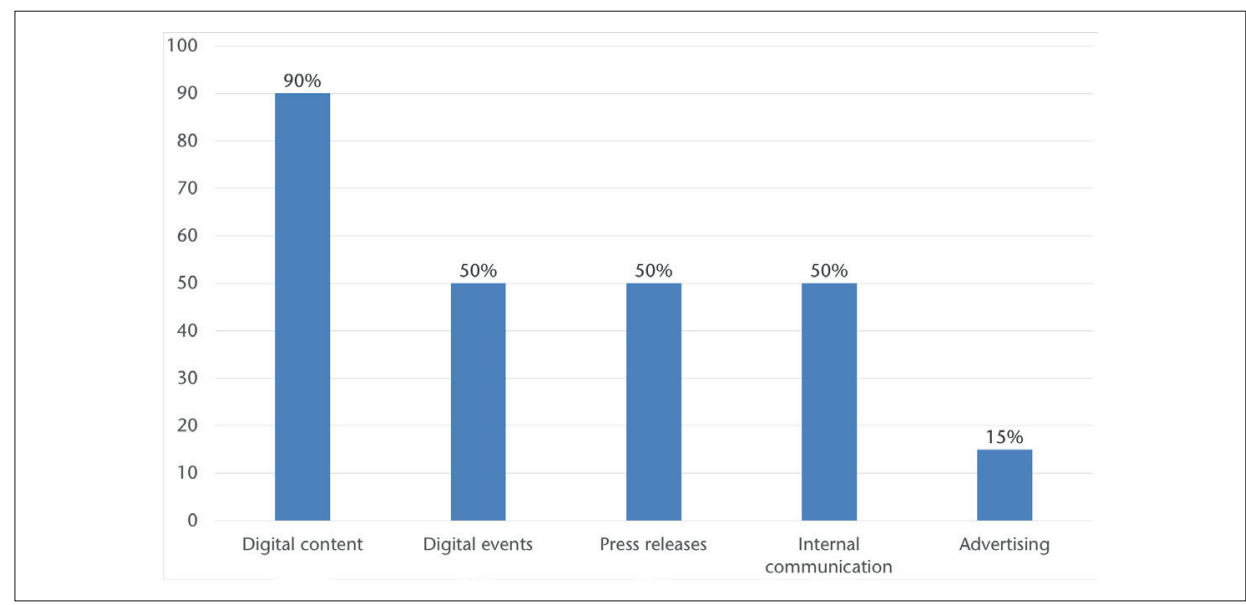

Source: Developed by the author.

When it came to implementing the communication actions that were planned and executed by the communication professionals participating in the study in the first month after Spain's declaration of the state of alarm in response to COVID-19, the main external communication channel for implementing the strategies of the digital companies they work with was social media, as compared to print media, television, and radio, which were also prominent channels, although to a lesser extent than digital media. 
Figure 7. External communication strategy, by channel

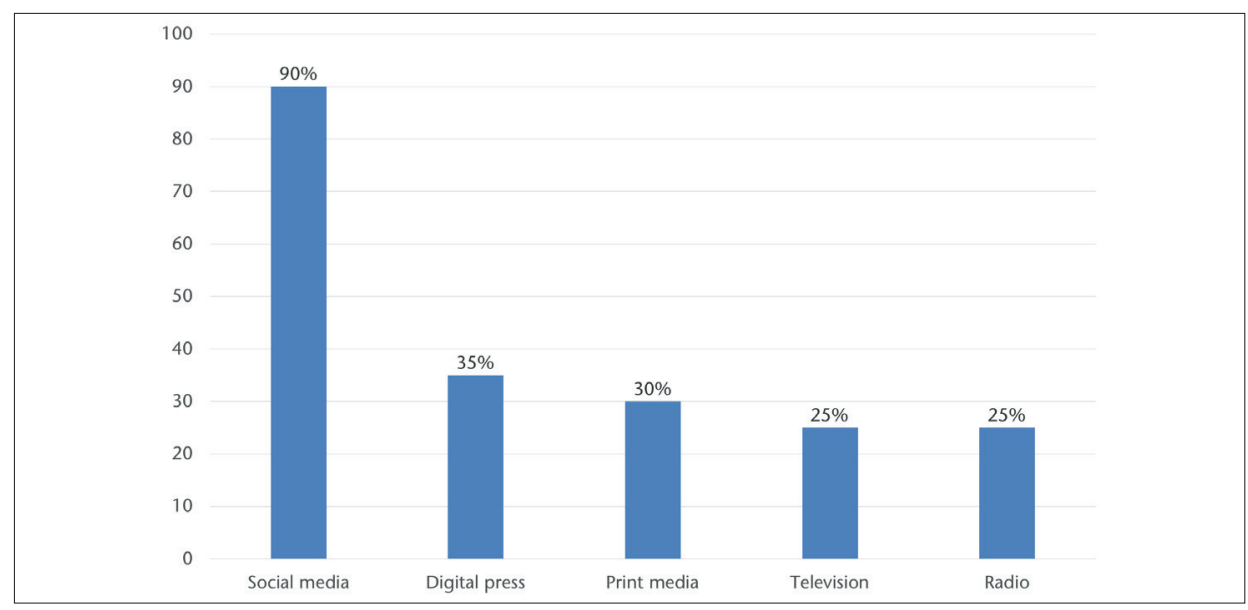

Source: Developed by the author.

From the point of view of message construction, 30\% of these communication actions used newsjacking techniques (Scott, 2010; Scott, 2011; Coll and Micó, 2019), relating their message to the current situation of the pandemic (McCombs and Shaw, 1972).

Figure 8. News-related messages (newsjacking)

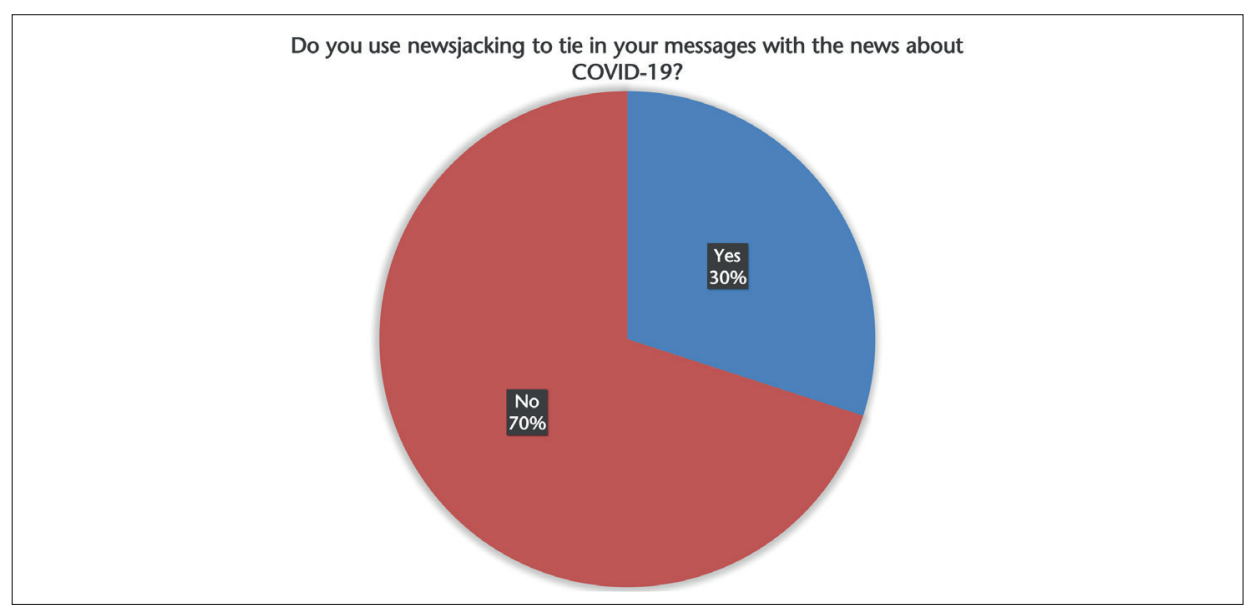

Source: Developed by the author.

In the specific case of internal communication actions, according to the communication professionals responsible for the strategies of the organisations from Barcelona's digital economy that participated in the study, the most-used channels during the 
first weeks of the COVID-19 crisis were: video calls (100\%) and email (100\%), which

were used by all the organisations. In addition, although to a lesser extent, instant messaging was used by $80 \%$ of companies as an internal communication channel, along with telephone calls, in $70 \%$ of cases, according to study participants.

Figure 9. Internal communication channels

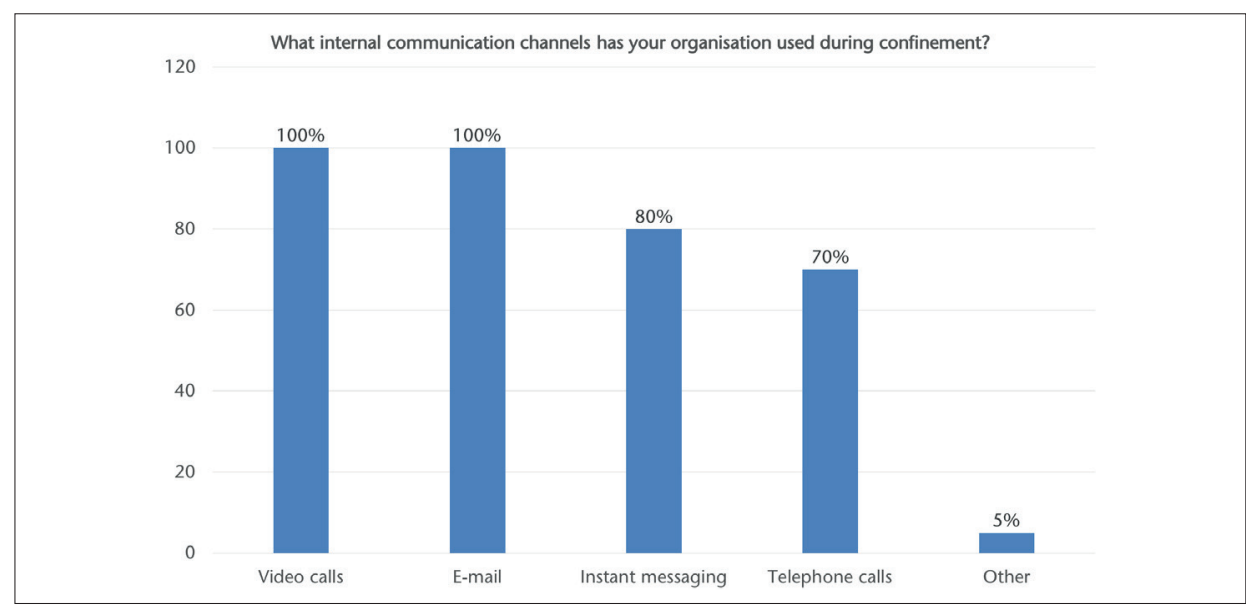

Source: Developed by the author.

Regarding the management of a crisis communication plan (Jin, 2010; Jin, Liu, and Austin, 2012; Coombs, 2014; Fearn-Banks, 2016), 60\% of the participants asserted that they did not develop a specific plan for the COVID-19 crisis, compared to $40 \%$ who said they did.

Figure 10. Developing a COVID-19 crisis communication plan

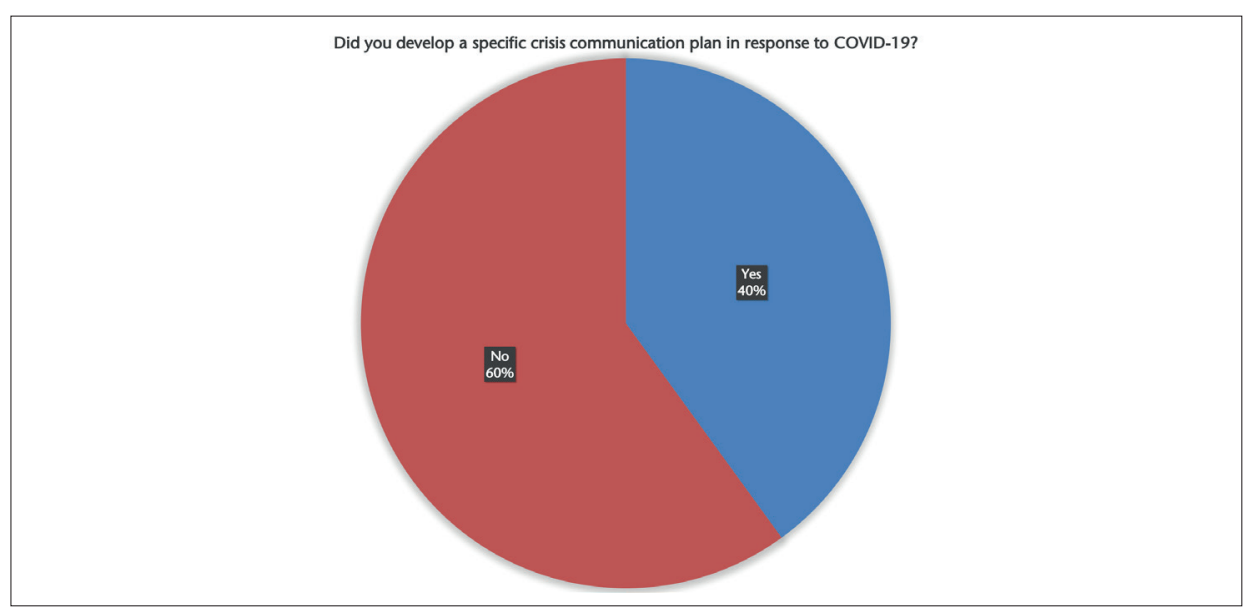




\section{CONCLUSIONS}

The study, carried out electronically from 1-15 April during the confinement in response to the COVID-19 health crisis in Spain (RDL 463/2020, dated 14 March; RDL 10/2020, dated 29 March), aimed to look at the changes in the communication strategies of organisations from the digital economy of Barcelona, the fifth European hub in terms of volume of start-ups (Atomico, 2019), during the first month following the declaration of the state of alarm in the country, just one month after the cancellation of the Mobile World Congress (GSMA, 2020a), the first of the mass events to be suspended in Spain due to the pandemic and the main yearly event for the sector under study.

The results presented in this article reveal the strategic decisions of these organisations and are of value for research in the communication disciplines, in a range of fields, such as digital marketing, advertising, journalism, corporate communication and public relations. The data provided by this research, carried out in near real time, lets us explore the approaches to crisis communication (Jin, 2010; Jin, Liu, and Austin, 2012; Coombs, 2014; Fearn-Banks, 2016) and strategic planning (Wilcox et al., 2012; Smith, 2013) among these digital native companies (Prensky, 2001) during a crucial period: the weeks after the cancellation of the Mobile World Congress, specifically in the first month following the declaration of the state of alarm in response to the health crisis due to the COVID-19 pandemic in Spain.

This period of time is especially relevant, since communication, in all types of media, was focused largely on messages related to the pandemic, and the internet became the main channel (Castells, 2004) as a result of the confinement ordered by the Spanish government to combat the health emergency caused by the novel coronavirus in the country (Legido-Quigley et al., 2020).

The participants confirmed the study's main hypothesis, centred on whether there was a change in the communication strategy within Barcelona's digital economy during the first weeks of the COVID-19 crisis, showing that $77 \%$ of companies altered the planning for their communication strategy during that period. In $73 \%$ of cases, companies opted for a proactive approach, focused mainly on the preparation and dissemination of digital content, the sending of press releases, the organisation of digital events, the execution of internal communication actions and, to a lesser extent, advertising, using a strategy that combined, on average, $60 \%$ of owned media with $27 \%$ earned media and $13 \%$ paid media. $30 \%$ of the messages disseminated through these communication actions tied in their message with the current situation of the coronavirus pandemic in order to connect with their audiences, implementing newsjacking techniques (Scott, 2010; Scott, 2011; Coll and Micó, 2019), given the dominance of pandemic-related news in the agenda setting (McCombs and Shaw, 1972).

The study reveals the predominant role of digital media in the initial weeks following the declaration of the state of alarm, due to the increased digitisation of target audiences during the confinement. During the first month, social networks and the digital press were the main communication channels as compared to traditional media such as print media, radio, or television. 
Patricia Coll-Rubio (patriciacr1@blanquerna. url.edu). PhD in Communication from the Ramon Llull University (URL). Director of the degree in Journalism and Corporate Communication at the Blanquerna School of Communica- tion and International Relations (URL). Author of books and academic articles on communication, as a journalist and researcher specialized in digital transformation, she collaborates with $E l$ País Retina, La Vanguardia and Wolters Kluwer.

\section{References}

Aced, C. (2018). Relaciones públicas 2.0. Barcelona: Editorial UOC.

Atomico (2019). "The State of the European Tech Report". Available at: <https://2019.stateofeuropeantech.com>. Accessed 1 April 2020.

Austin, E. W. and Pinkleton, B. E. (2000). Strategic Public Relations Management: Planning and Managing Effective Communication Programs. New York: Taylor \& Francis.

Berger, J. and Milkman, K. L. (2012). "What Makes Online Content Viral?". Journal of Marketing Research, 49(2), pp. 192-205.

Bernays, E. L. (1923). Crystallizing Public Opinion. New York: Boni \& Liveright.

Brown, D. and Hayes, N. (2008). Influencer Marketing. Oxford: Elsevier.

Campbell, C. and Marks, L. J. (2015). "Good Native Advertising Isn't a Secret". Business Horizons, 58(6), pp. 599-606.

Castells, M. (2004). The Network Society: A Cross-Cultural Perspective. Cheltenham: Edward Elgar.

Cea d'Ancona, M. A. (1996). Metodología cuantitativa. Estrategias y técnicas de investigación social. Madrid: Síntesis.

Chaffey, D. and Ellis-Chadwick, F. (2019). Digital Marketing. London: Pearson.

Chen, A. (2012). "Growth Hacker Is the New VP Marketing". Andrew Chen. Available at: <http://andrewchen.co/how-to-be-agrowth-hacker-an-airbnbcraigslist-case-study/>. Accessed 1 April 2020.

Coll, P. and Micó, J. Ll. (2019). Newsjacking Posdigital. El secuestro de noticias en la estrategia de comunicación. Barcelona: Editorial UOC.
Coombs, W. T. (2014). Ongoing Crisis Communication: Planning, Managing, and Responding. London: Sage Publications.

Cuenca-Fontbona, J.; Matilla, K., and Compte-Pujol, M. (2020). “Transformación digital de los departamentos de relaciones públicas y comunicación de una muestra de empresas españolas". Revista de Comunicación, 19(1), pp. 75-92. DOI: <https://doi.org/10.26441/ RC19.1-2020-A5>.

Dubber, A. (2014). Radio in the Digital Age. New Jersey: John Wiley \& Sons.

Ellis, S. (26 July 2010). "Find a Growth Hacker for Your Startup". Startup Marketing. Available at: <http://www.startup-marketing.com/ where-are-all-the-growth-hackers/>. Accessed 1 April 2020.

Ellis, S. and Brown, M. (2018). El método Hacking Growth. Qué hacen compañias explosivas como Facebook, Airbnb y Walmart para ser líderes en el mercado. Barcelona: Penguin Random House.

Fearn-Banks, K. (2016). Crisis Communications: A Casebook Approach. London: Routledge.

Grunig, J. E. and Hunt, T. (1984). Managing Public Relations. New York: Holt, Rinehart and Winston.

GSMA (2020a). "GSMA Statement on MWC Barcelona 2020 from John Hoffman, CEO GSMA Limited". Available at: <https:// www.gsma.com/newsroom/press-release/ gsma-statement-on-mwc-barcelona-2020/>. Accessed 1 April 2020.

-. (2020b). "GSMA and Host City Parties Extend MWC Barcelona Agreement". Availa- 
ble at: <https://www.gsma.com/newsroom/ statement/gsma-and-host-city-parties-extendmwc-barcelona-agreement/>. Accessed 1 April 2020.

Holiday, R. (2014). Growth Hacker Marketing: A Primer on the Future of PR, Marketing, and Advertising. New York: Penguin.

Howard, P. N. (2006). New Media Campaigns and the Managed Citizen. New York: Cambridge University.

Howe, P. and Teufel, B. (2014). "Native Advertising and Digital Natives: The Effects of Age and Advertisement Format on News Website Credibility Judgements". ISOJ Journal, 4(1).

Jin, Y. (2010). "Making Sense Sensibly in Crisis Communication: How Publics' Crisis Appraisals Influence Their Negative Emotions, Coping Strategy Preferences, and Crisis Response Acceptance". Communication Research, 37(4), pp. 522-552.

Jin, Y.; Liu, B. F., and Austin, L. (2012). "How Audiences Seek Out Crisis Information: Exploring The Social-Mediated Crisis Communication Model". Journal of Applied Communication Research, 40(20), pp. 188-207.

Jurvetson, S. and Draper, T. (1997). "Viral Marketing: Viral Marketing Phenomenon Explained". DFJ Network News. Available at: <https:// es.scribd.com/document/133798561/08Tim-Draper-on-Viral-Marketing>. Accessed 1 April 2020.

Kaushik, A. (2010). Analítica web 2.0. Barcelona: Gestión 2000.

Kelly, K. (1997). "New Rules for the New Economy". Wired. Available at: <https://www. wired.com/1997/09/newrules/>. Accessed 1 April 2020.

Kliatchko, J. (2005). "Towards a New Definition of Integrated Marketing Communications (IMC)". International Journal of Advertising, 24(1), pp. 7-34.

Kotler, P. (2003) Marketing Management. New Jersey: Prentice Hall.

L'Etang, J. (2009). "Public Relations and Diplomacy in a Globalized World: An Issue of
Public Communication". American Behavioral Scientist, 53(4), pp. 607-626.

Legido-Quigley, H.; Mateos-García, J. T.; Campos, V. R.; Gea-Sánchez, M.; Muntaner, C., and McKee, M. (2020). "The Resilience of the Spanish Health System Against the COVID-19 Pandemic". The Lancet Public Health 2020. Available at: <https:// www.thelancet.com/action/showPdf?pii $=$ S2468-2667\%2820\%2930060-8>. Accessed 1 April 2020.

Marston, J. E. (1963). The Nature of Public Relations. New York: McGraw-Hill.

Maskeroni, A. (2016). "Why Ads Go Viral, and What Made Apple's 'Taylor vs. Treadmill' the Perfect Viral Spot". Adweek. Available at: <http://www.adweek.com/brand-marketing/ why-ads-go-viral-and-what-made-applestaylor-vs-tread mill-perfect-viralspot-171101/>. Accessed 1 April 2020.

McCombs, M. E. and Shaw, D. L. (1972). "The Agenda-Setting Function Of Mass Media". Public Opinion Quarterly, 36(2), pp. 176187.

Micó, J. Ll. and Coll, P. (2020). Hiperaceleración. Barcelona: Diëresis.

Miller, V. (2020). Understanding Digital Culture. London: SAGE Publications Limited.

Patel, N. and Taylor, B. (2014). "The Definite Guide to Growth Hacking". QuickSprout. Available at: <https://www.quicksprout.com/ the-definitive-guide-to-growth-hacking/>. Accessed 1 April 2020.

Prensky, M. (2001). "Digital Natives, Digital Immigrants". On the Horizon, 9(5). Available at: DOI: <https://doi. org/10.1108/10748120110424816>. Accessed 1 April 2020.

Pulizzi, J. and Barrett, N. (2009). Get Content Get Customers: Turn Prospects into Buyers with Content Marketing. New York: McGraw Hill Professional.

Pulizzi, J. (2015). "Native Advertising Is not Content Marketing". Content Marketing Institute. Available at: <http://content marketinginstitute.com/2015/08/native- 
advertising-content-marketing/>. Accessed 1 April 2020.

Qvortrup, L. (2006). "Understanding New Digital Media: Medium Theory or Complexity Theory?". European Journal of Communication, 21(3), pp. 345-356. DOI: <https://doi. org/10.1177/0267323106066639>.

Rosen, E. (2002). The Anatomy of Buzz. New York: Crown Publishing Group.

Rushkoff, D. (1994). Media Virus. New York: Random House Publishing Group.

Sallot, L. M.; Cameron, G. T., and Lariscy, R. A. W. (1997). Professional Standards in Public Relations: A Survey of Educators.

Schultz, D. E. and Kitchen, P. J. (2000). “A Response to "Theoretical Concept or Management Fashion'". Journal of Advertising Research, 40(5), pp. 17-21.

Scott D. M. (2010). The New Rules of Marketing and PR: How To Use Social Media, Blogs, News Releases, Online Video, and Viral Marketing to Reach Buyers Directly. New Jersey: John Wiley \& Sons.

-. (2011). Newsjacking Your Way into Media. New Jersey: John Wiley \& Sons.

Smith, R. D. (2013). Strategic Planning for Public Relations. London: Routledge.
Spanish Royal Decree-Law 463/2020, dated 14 March, declaring the state of alarm for the purpose of managing the health crisis caused by COVID-19. Official State Gazette (BOE), 14 March 2020, no. 67, pp. 2539025400 .

-. 10/2020, dated 29 March, which regulates a recoverable paid leave for employees who do not provide essential services, in order to reduce the mobility of the population in the context of the fight against COVID-19. Official State Gazette (BOE), 29 March 2020, no. 67, pp. 27629-27636.

Steinberg, C. S. (1975). The Creation of Consent: Public Relations in Practice. Winter Park (USA): Hastings House Book Publishers.

Thompson, J. B. (2005). "The New Visibility". Theory, Culture \& Society, 22(6), pp. 31-51

Tuten, T. L. and Solomon, M. (2018). Social Media Marketing. London: Sage.

Wellman, B. and Haythornthwaite, C. A. (2002). The Internet in Everyday Life. Malden: Blackwell.

Wilcox, D. L; Cameron, G.T., and Xifra, J. (2012). Relaciones públicas. Estrategias y tácticas. Madrid: Pearson Educación. 
